\title{
DARI KONVERSI KE RESISTENSI: STRATEGI KEBERTAHANAN AGAMA LOKAL DALAM PUSARAN PLURALITAS TERBATAS
}

\author{
Apriliyani Harahap \\ Universitas Islam Negeri (UIN) Sunan Kalijaga Yogyakarta, barahapapriliyani@gmail.com \\ Zaenuddin Zaenuddin \\ Universitas Islam Negeri (UIN) Sunan Kalijaga Yogyakarta, alizainuddin02@gmail.com
}

(C)2020 by the authors. Submitted for possible open access publication under the terms and conditions
of the Creative Commons Attribution-ShareAlike 4.0 International License (CC-BY-SA)
license (https://creativecommons.org/licenses/by-sa/4.0/)
do DOI: http://dx.doi.org/10.30983/fuaduna.v4i2.3381
\begin{tabular}{|c|c|c|}
\hline Diterima: 05 Agustus 2020 & Direvisi: 23 Desember 2020 & Diterbitkan: 31 Desember 2020 \\
\hline
\end{tabular}

\begin{abstract}
This article discusses the construction of defining religion in Indonesia which cannot be separated from the influence of the world religions paradigm. Indonesia is one of the countries that has implemented a religious management policy based on recognition, through Law no. 1/PNPS 1965 concerning the Prevention of Religious Abuse and/or Blasphemy. This research article focuses on examining how the patterns and strategies adopted by the adherents of local religions in Indonesia can exist in the middle of the vortex of recognition of official religions by the state. With the library research method analyzed using a content analysis approach, this article finds that the patterns and strategies used by adherents of local religions to maintain their existence are conversion or conversion, religious syncretism, and resistance, namely refuses to be affiliated with world religions. The various patterns and strategies that have emerged are the response of local religions to various state policies that co-opt their rights, especially civil rights in services and fulfillment of their needs, including civil registration, access to education, health facilities and facilities, to the registration of marriage.
\end{abstract}

Keywords: Conversion; Syncretism; Resistance; Indigenous Religion; Limited Pluralism.

\begin{abstract}
Abstrak
Artikel ini membahas tentang konstruksi pendefinisian agama di Indonesia yang tidak lepas dari pengaruh paradigma agama dunia. Indonesia merupakan salah satu negara yang menerapkan kebijakan pengelolaan agama berdasarkan pengakuan, melalui UU No. 1/PNPS Tahun 1965 Tentang Pencegahan Penyalahgunaan dan/atau Penodaan Agama. Riset artikel ini fokus untuk mengkaji bagaimana pola dan strategi yang diterapkan oleh para penganut agama lokal di Indonesia agar dapat eksis di tengah pusaran pengakuan agama-agama resmi oleh negara. Dengan metode studi kepustakaan (library research) yang dianalisis menggunakan pendekatan analisis isi (content analysis), artikel ini menemukan bahwa pola dan strategi yang digunakan oleh penganut agama lokal dalam mempertahankan eksistensinya adalah dengan melakukan konversi atau pindah agama, sinkretisme agama, dan resistensi, yakni menolak untuk diafiliasikan dengan agama dunia. Ragam pola dan strategi yang mengemuka ini sebagai respon agama lokal terhadap berbagai kebijakan negara yang mengkooptasi hak-hak mereka, terutama hak-hak sipil dalam pelayanan dan pemenuhan kebutuhannya, baik pencatatan sipil, akses pendidikan, sarana dan fasilitas kesehatan, hingga pencatatan perkawinan.
\end{abstract}

Kata Kunci: Konversi; Sinkretisme; Resistensi; Agama Lokal; Pluralitas Terbatas. 


\section{PENDAHULUAN}

Indonesia merupakan sebuah negara dengan komposisi masyarakat yang multikultural atau beragam, baik dari aspek etnisitas atau suku, agama, bahasa, maupun kebudayaannya. Keberagaman tersebut merupakan suatu fakta heterogenitas yang tidak dimiliki oleh bangsabangsa lainnya. Salah satu keberagaman di Indonesia yang memiliki daya tarik dan pengaruh magis bagi masyarakatnya adalah aspek agama dan kepercayaan. Hal tersebut dilandasi oleh pengaruh agama itu sendiri yang dianggap sebagai satusatunya sumber moral yang paling tinggi oleh para pengikut atau penganutnya. Selain itu, agama diposisikan sebagai unsur yang memiliki kesucian dan dan keagungan. Atas dasar itulah, lahirlah sebuah sikap dan perilaku penghormatan secara totalitas, pengkultusan, dan sikap fanatisme dari para pengikutnya, yang pada akhirnya memunculkan sikap eksklusivisme. ${ }^{1}$ Ekslusivisme dapat dipahami sebagai kecenderungan pengikut agama tertentu yang melihat dan memposisikan agama atau keyakinannya sebagai satu-satunya kebenaran, dan di saat yang bersamaan, memandang keyakinan orang-orang yang berada di luar kelompoknya sebagai kesesatan dan penyimpangan.

Mengkaji seputar aspek keberagaman keagamaan di Indonesia, secara konstitusional telah diatur dalam Undang-undang Dasar Tahun 1945 pasal 28E ayat (1) yang berbunyi "setiap orang bebas memeluk agama dan beribadat menurut agamanya". Artinya, kebebasan dan kemerdekaan dalam beragama merupakan hak bagi setiap orang dan negara memfasilitasi serta memberikan jaminan kepada setiap warga negaranya dalam mengekspresikan kebebasan beragama dan beribadah menurut agamanya.

${ }^{1}$ Abdul Hanan, "Fanatisme Dan Stigma Sosial Pesantren Miftahul Ulum Terhadap Kelompok Ahmadiyah Di Pamekasan" (Tesis, Universitas Airlangga, 2006), 169.

${ }^{2}$ Ismatu Ropi, Religion and Regulation in Indonesia (Singapore: Palgrave Macmillan, 2017), 15, https://doi.org/10.1007/978-981-10-2827-4.
Menindaklanjuti adanya keberagaman keagamaan di Indonesia, negara mengambil peran dengan melakukan manuver manajemen agama atau pengelolaan agama melalui sebuah kebijakan. Menurut Paul Weithman, dalam Ismatu Ropi, terdapat tiga bentuk atau relasi kebijakan dalam sebuah negara mengenai agama, yakni penyatuan, pemisahan, dan pengakuan. ${ }^{2}$ Adapaun pola kebijakan yang diadopsi oleh Indonesia terhadap agama yaitu pengakuan.

Sejauh ini, negara hanya mengakui enam agama resmi di Indonesia, yakni Islam, Kristen, Katolik, Hindu, Buddha, dan Konghucu. Pengakuan terhadap keberagaman agama di Indonesia, tidak terlepas dari adanya pengaruh politik, hukum dan sosio-historis tahun 1950-1966 yang menggambarkan situasi dan kondisi pada saat itu, ditemukan berbagai organisasi atau aliranaliran kepercayaan masyarakat lokal yang bertentangan dan bertolak belakang dengan ajaranajaran serta hukum agama yang hampir tersebar di seluruh daerah di Indonesia. Aliran-aliran tersebut dianggap telah melakukan penodaan terhadap agama, melanggar hukum dan berpotensi menimbulkan hal-hal yang dapat memecah belah persatuan dan melanggar hukum. Demikian pula dengan kondisi politik kala itu yang sudah memasuki taraf darurat karena adanya pembangkangan serta usaha-usaha inkonstitusional yang digagas oleh kelompok atau aliran kepercayaan dalam menggagalkan usahausaha partai Islam dalam Pemilu 1955, ${ }^{3}$ sebagaimana yang diulas oleh Niels Mulder dalam "Mysticism and Everyday Life in Contemporary Java: Cultural Persistence and Change".

Berangkat dari situasi yang demikian, Soekarno selaku presiden, memandang bahwa diperlukan suatu sikap yang tegas dalam merespon permasalahan tersebut agar tercipta situasi dan

3 James A. Boon, "Mysticism and Everyday Life in Contemporary Java: Cultural Persistence and Change" The Journal of Asian Studies 38, no. 2 (1979): 428-431, https://doi.org/10.2307/2053491; Sudarto, "Rekognisi Agama Lokal Prasyarat Menuju Demokrasi Majemuk", Jurnal Fuaduna: Jurnal Kajian Keagamaan dan Kemasyarakatan 3, no. 2 (2019): 92-105, https://10.30983/fuaduna.v3i2.2547. 
kondisi yang aman dan kondusif dengan mengeluarkan Penetapan Presiden (PP) No. 1 (selanjutnya ditulis PNPS/1965 sebagaimana yang kita kenal saat ini), sebagai realisasi Dekrit Presiden tanggal 5 Juli 1959. Upaya tersebut dianggap sebagai salah satu pilihan untuk menyalurkan ketatanegaraan dan keagamaan. Sehingga, rakyat di seluruh Indonesia bisa menikmati ketenteraman beragama dan jaminan dalam menunaikan ibadah menurut agamanya masing-masing. ${ }^{4}$

Terdapat dua alasan yang melatarbelakangi pembentukan Penetapan Presiden ini, yakni: Pertama, sebagai bentuk pengamanan negara terkait dengan upaya pencegahan dan atau penodaan agama. Kedua, memberikan rasa aman dan ketenteraman bagi masyarakat. ${ }^{5}$ Terkait poin kedua, lahirnya Peraturan Presiden yang kemudian dikuatkan dan ditingkatkan statusnya menjadi Undang-undang Nomor 5 Tahun 1965 Tentang Pernyataan Berbagai Penetapan Presiden dan Peraturan Presiden Sebagai Undang-undang, merupakan sebuah senjata yang digunakan oleh negara dalam membendung dan membentengi agama-agama resmi dari pengaruh agama lokal. ${ }^{6}$ Sehingga penganut agama-agama resmi dapat menjalankan ritual keagamaannya masing-masing, tanpa dipengaruhi oleh doktrin agama lokal.

Implikasi dari lahirnya Undang-undang No.1/PNPS Tahun 1965 menjadi ancaman bagi eksistensi agama-agama lokal dan pengikutnya karena tidak mendapatkan pengakuan, sebagaimana yang dijelaskan dalam pada bagian I (Umum) poin kedua yang menyebutkan diksi "membahayakan Agama-agama yang ada". Frasa "Agama-agama yang ada" di dalam UU tersebut merujuk pada agama-agama resmi di Indonesia yang telah mendapatkan pengakuan oleh negara. Sehingga agama-agama lokal atau penghayat

${ }^{4}$ Yasser Arafat, "Analisis Undang-Undang Nomor 1/PNPS/ Tahun 1965 Tentang Pencegahan Penyalahgunaan dan/atau Penodaan Agama" (Skripsi, Universitas Sebelas Maret, 2010), 62.

${ }^{5}$ Hwian Christianto, "Arti Penting Pemberlakuan UU No. 1/PNPS/1965,'Jurnal Hukum dan Pembangunan 41, no. 3 (2011): 366, https://doi.org/10.21143/jhp.vol41.no3.251. kepercayaan bukan merupakan agama atau setara dengan agama. Negara mengelompokkan penganut agama lokal sebagai kelompok yang tidak memiliki agama, sehingga mereka harus selalu diawasi. ${ }^{7}$ Dampak negatifnya adalah hak-hak konstitusionalnya sebagai warga negara cenderung terdiskriminasi, bahkan terpinggirkan, serta mereka kerap kesulitan dalam mengakses dan memenuhi hak-haknya.

Selain menerima perlakuan diskriminatif, penganut agama lokal, maupun aliran kepercayaan lainnya, kerap dikelompokkan sebagai subyek yang menyimpang dari ajaran agama-agama yang diakui pemerintah. Fenomena ini terkonfirmasi berdasarkan laporan tahunan kehidupan beragama di Indonesia tahun 2012 yang mencatat sebanyak 22 kasus penodaan agama. Adapun 20 kasus di antaranya terkait dengan perbedaan praktik dan pemahaman keagamaan yang dianggap sesat atau menyimpang oleh pemerintah. ${ }^{8}$ Diantaranya adalah kelompok Ahmadiyah, Syi'ah dan Majelis Tafsir Al-Qur'an (MTA).

Berkaitan dengan stereotyping menyimpang atau sesat yang diuraikan di atas, Sapta Darma, sebagai salah satu agama lokal di Indonesia, kerap dikelompokkan sebagai kepercayaan yang menyimpang dan pengikutnya dianggap orang sesat. Pelabelan atau stereotyping menyimpang dan sesat tersebut diuraikan oleh Jayyidan dan Rohit dalam artikelnya "Pengikut Sapta Darma di Tengah Pluralitas Terbatas." Temuan penelitiannya mengungkapkan bahwa pengikut Sapta Darma mengalami eksklusi sosial di masyarakat dalam bentuk stereotyping orang sesat dan gila. Pelabelan gila dan sesat, merupakan anggapan warga sekitar yang hidup berdekatan dengan penganut Sapta Darma. Tata cara ritual ibadah Kepercayaan Sapta Darma dalam bentuk berdiam diri, menyedekapkan

${ }^{6}$ Tedi Kholiludin, Kuasa Negara atas Agama: Politik Pengakuan, Diskursus AgamaResmidan Diskriminasi Hak Sipil (Semarang: RaSAIL, 2009), 159.

${ }^{7}$ Ibid, 329.

${ }^{8}$ Zainal Abidin Bagir et.al., Laporan Tabunan Kebidupan Beragama di Indonesia 2012 (Yogyakarta: CRCSUGM, 2012), 18. 
tangan di perut, dan memejamkan mata dianggap memiliki kemiripan dengan orang gila serta jauh berbeda dari ritual ibadah agama-agama lainnya yang diakui pemerintah. Di bidang pelayanan administratif misalnya, penganut Sapta Darma berkali-kali mengalami kendala dalam memperoleh Kartu Tanda Penduduk (KTP). Penyebabnya adalah karena ketidaktahuan petugas pelayanan pencatatan sipil dalam melayani penganut Sapta Darma, khususnya pada pencantuman agama. Dan pada akhirnya, penganut Sapta Darma lebih memilih mengosongkan kolom agama di KTP mereka serta menolak tawaran untuk diafiliasikan ke dalam agama-agama resmi. ${ }^{9}$

Demikian pula yang dialami oleh penganut Marapu di Sumba, Nusa Tenggara Timur. Perlakuan diskriminatif yang dialami oleh kelompok keyakinan tersebut merambah ke dunia pendidikan formal. Melalui pendidikan, negara menjadikannya sebagai alat untuk melakukan formalisasi beragama bagi anak-anak penganut Marapu. Formalisasi itu sendiri dimaknai sebagai sebuah proses penyesuaian beragama berdasarkan peraturan perundang-undangan yang sah. Secara tidak langsung, negara telah memposisikan penganut Marapu sebagai kelompok yang belum beragama. Sehingga, anak-anak mereka sebagai peserta didik yang ingin mengenyam pendidikan formal, dituntut serta diharuskan untuk menganut salah satu agama yang diakui secara yuridis oleh negara, sebagaimana yang dijelaskan dalam UU No. 1/PNPS Tahun 1965 tentang Pencegahan Penyalahgunaan dan/atau Penodaan Agama. Penegasan pengakuan negara atas agama di sektor pendidikan termanifestasi dalam UU RI Nomor 20 Tahun 2003 Tentang Sistem Pendidikan Nasional (Sisdiknas). Pada pasal 12 ayat (1A) disebutkan bahwa "setiap peserta didik pada setiap satuan pendidikan berhak mendapatkan pendidikan agama

'Jayyidan Falakhi Mawaza and Rohit Mahatir Manese, "Pengikut Sapta Darma Di Tengah Pluralitas Terbatas," Palita: Journal of Social Religion Research (2020).

${ }^{10} \mathrm{Ida}$ Bagus Oka Wedasantara and I Nyoman Suarsana, "Formalisasi Beragama Penganut Marapu Melalui sesuai dengan agama yang dianutnya dan diajarkan oleh pendidikyang seagama." Kemudian pada pasal 37 ayat (1A) "Kurikulum pendidikan dasar dan menengah wajib memuat pendidikan agama." Pada praktiknya, anakanak pengikut Marapu didoktrin terlebih dahulu melalui ajaran-ajaran Alkitab, saat berlangsungnya mata pelajaran pendidikan agama Kristen/Katolik. Selain itu, mereka diwajibkan untuk megikuti sekolah minggu. Melalui sekolah minggu, anakanak penganut Marapu diajarkan nyanyian rohani agar dapat dipentaskan di gereja. Adapun respon dari orangtua penganut Marapu, terhadap tindakan serta perlakuan yang demikian terhadap anak-anak mereka adalah mendiamkan. Sebab, apabila ada resistensi atau penolakan terhadap upaya yang demikian, maka anak-anak mereka akan kesulitan dan kesusahan dalam mengakses pendidikan. Tidak sedikit diantara anak-anak penganut Marapu telah dibaptis atau dikonversi ke agama Kristen. ${ }^{10}$

Hal yang serupa, dialami juga oleh penganut Towani Tolotang di Sulawesi Selatan, sebagaimana yang terdeskripsikan dalam salah satu penelitian yang dilakukan oleh Hasse J. dalam artikelnya "Kebijakan Negara Terhadap Agama Lokal Towani Tolotang di Kabupaten Sidrap Sulawesi Selatan”. Hasse mengungkapkan bahwa Agama Towani Tolotang dikonversi menjadi Agama Hindu, sesuai dengan keputusan Direktorat Jenderal Bimbingan Masyarakat (BIMAS) Hindu Bali/Buddha No. 2 Tahun 1966 yang menyebutkan bahwa Towani Tolotang merupakan salah satu bagian dari sekte agama Hindu. ${ }^{11}$ Konversi atau pengafiliasian pengikut Towani Tolotang ke dalam agama Hindu, kerap didasarkan pada alasan-alasan yang bersifat pragmatis, seperti akses pencatatan sipil, pelayanan kesehatan, pendidikan dan pencatatan pernikahan. Segala bentuk kepentingan pengikut Agama Towani Tolotang, baik administratif atau yang lainnya,

Pendidikan Formal Pada Masyarakat Kampung Tarung Di Sumba Barat, NTT," Humanis (2019).

${ }^{11}$ Hasse J, "Kebijakan Negara Terhadap Agama Lokal 'Towani Tolotang' di Kabupaten Sidrap, Sulawesi Selatan," Journal of Government and Politics, (2010): 166, https://doi.org/10.18196/jgp.2010.0009. 
didasarkan pada identitas Agama Hindu. Cara ini ditempuh agar penganut agama lokal dapat memperoleh hak dan pelayanan, sebagaimana pengikut agama resmi lainnya. ${ }^{12}$

Berangkat dari permasalahan yang telah penulis ulas, artikel ini bertujuan untuk mengkaji bagaimana pola eksistensi yang diterapkan oleh para penganut agama Lokal di Indonesia di tengah pusaran pengakuan agama-agama resmi oleh negara. Adapun metode yang digunakan oleh penulis dalam mengkaji permasalahan di atas menggunakan studi kepustakaan (library research) yang dianalisis menggunakan teknik analisis isi. Karena analisis isi khusus digunakan dalam pemrosesan data ilmiah. Tujuannya adalah untuk dapat memberikan pengetahuan, menyajikan sebuah fakta, dan membuka wawasan yang baru. ${ }^{13}$ Dengan demikian maka, dapat diketahui pola-pola yang mereka gunakan dalam memperjuangkan hak-haknya sebagai warga negara Indonesia.

\section{KONSTRUKSI MAKNA AGAMA}

Pendefinisian terhadap agama di Indonesia begitu ketat, meskipun definisi yang digunakan merupakan warisan konstruksi Barat pada abad ke19 tentang paradigma agama dunia, yang kental mengandung nilai-nilai yang bersifat esensial dan memiliki superioritas. Di Indonesia, agama yang dijadikan sebagai prototipe agama dunia adalah Islam, karena mayoritas penduduk Indonesia merupakan pemeluk agama Islam. Pendefinisian agama telah dilakukan sejak terbentuknya Departemen Agama pada awal tahun 1946 yang bertujuan untuk melakukan pengelolaan agama. Pada tahun 1952, Departemen Agama mengusulkan sebuah definisi agama yang

${ }^{12}$ Hasse J, "Dinamika Hubungan Islam Dan Agama Lokal Di Indonesia: Pengalaman Towani Tolotang Di Sulawesi Selatan," Wawasan: Jurnal Ilmiah Agama Dan Sosial Budaya, (2016): 182, https://doi.org/10.15575/jw.v1i2.744.

${ }^{13}$ Klaus Krispendoff, Analisis Isi Pengantar Teori Dan Metodologi (Yogyakarta Penerbit Kanisius, 1993), 15.

${ }^{14}$ Samsul Maarif, "Meninjau Ulang Definisi Agama, Agama Dunia, dan Agama Leluhur" dalam Ihsan Ali Fauzi mencakup tiga elemen, yakni: nabi, kitab suci, dan pengakuan internasional. ${ }^{14}$

Pengusulan atas definisi agama diinisiasi oleh Muhammad Dimyati, dalam sebuah sidang Dewan Perwakilan Rakyat (DPR). Dimyati menuntut agar kelompok aliran kebathinan dilarang. Hal ini kemudian direspon oleh Departemen Agama dengan membuat sebuah rumusan mengenai apa yang disebut agama. Maka pada saat itulah disusun dan dirumuskannya unsurunsur yang sangat mendasar atau bersifat esensial mengenai agama, yakni adanya Nabi atau rasul, kitab suci, dan pengakuan secara internasional atau pengakuan sebagai agama secara internasional. ${ }^{15}$

Kiblat dari pendefinisian ini adalah agama Islam. Artinya, apabila agama-agama lain di luar Islam, menghendaki adanya pengakuan oleh negara, maka Islam adalah rujukannya dengan syarat telah memenuhi ketiga elemen definisi agama. Sebagaimana penganut agama Hindu dan Buddha yang harus dimonoteistikkan agar mendapatan pengakuan dari negara. ${ }^{16}$ Sedangkan kelompok agama tertentu yang tidak mampu beradaptasi dengan pendefinisian tersebut, maka secara terpaksa mereka harus menerima perlakuan diskriminatif, serta eksklusi yang berujung pada terpinggirkannya hak-hak mereka.

Mulder menguatkan tentang elemen yang digunakan oleh Departemen Agama dalam mendefisinikan agama, bahwa agama didefinisikan sebagai sesuatu yang memiliki kitab suci, Nabi atau rasul, doktrin Ketuhanan Yang Maha Esa dan mendapatkan pengakuan internasional. ${ }^{17}$ Gagasan ini kemudian diperkuat oleh Bowie bahwa pengakuan negara terhadap agama didasarkan pada beberapa aspek inti, diantaranya adalah sebagai berikut:

et.al., Kebebasan, Toleransi, dan Terorisme: Riset dan Kebijakan Agama di Indonesia (Jakarta: PUSAD Paramadina, 2017), 16.

${ }^{15}$ Rahmat Subagya, Kepercayaan dan Agama (Yogyakarta: Kanisius, 1995), 116.

${ }^{16}$ Zainal Abidin Bagir, "Mengkaji Agama di Indonesia", dalam Samsul Ma'arif Studi Agama di Indonesia: Refleksi Pengalaman (Yogyakarta: CRCS-UGM, 2016), 22.

${ }^{17}$ Samsul Maarif, "Meninjau Ulang Definisi Agama, Agama Dunia, dan Agama Leluhur"..., 32. 
1. Memiliki kitab suci yang tertulis (based on written scripture).

2. Adanya petunjuk atau wahyu yang disampaikan atau diturunkan oleh Tuhan kepada para Nabi-Nya.

3. Merupakan agama yang universal dan dianut oleh berbagai kelompok sosial di dunia.

4. Memiliki potensi untuk menghegemoni agama pribumi.

5. Adanya sistem ritual yang dilakukan oleh kelompok masyarakat penganutnya. ${ }^{18}$

Polemik pendefinisian mengenai agama, dijadikan oleh negara sebagai instrumen justifikasi pembedaan dan penundukan bagi kelompok lainnya. Pendefinisian tersebut tentunya sangat hegemonik karena agama didefinisikan secara esenasialis berdasarkan perspektif kelompok mayoritas tertentu atau etnosentris. Terminologis tersebut cenderung bersifat teologis dan bias politis karena hanya mengakomodasi agamaagama tertentu yang telah mendapatkan pengakuan negara. Sehingga agama-agama lokal berikut pengikutnya terdiskriminasi dan tidak diakui sebagai agama. ${ }^{19}$ Selain itu, definisi agama yang digunakan akan melahirkan persepektif dikotomis-kategoris terhadap agama, yakni dikotomi agama resmi dan tidak resmi, agama modern dan agama primitif. ${ }^{20}$ Pengelompokkan ini dilakukan oleh pemegang kekuasaan, baik secara politik ataupun agama, sehingga konstruksi dari definisi yang dibangun, sarat dengan kepentingan.

Agama-agama lokal yang hidup dan berkembang di Indonesia tidak berdasarkan definisi esensial yang diformulasikan oleh negara. Agama atau kepercayaan lokal merupakan agama atau keyakinan yang berkembang dan diyakini kebenarannya oleh suatu komunitas atau kelompok di daerah tertentu serta memiliki ciri-ciri utama yakni keyakinan terhadap Tuhan Yang

${ }^{18}$ Moh. Soehadha, "Pengertian Antropologis Tentang Agama Dan Pengertian Oleh Negara Tentang Agama Di Indonesia,"Esensia 6, no. 2 (Juli 2005), 189.

${ }^{19}$ Rahmat Subagya, Kepercayaan - Kebatinan Kerohanian - Kejiwaan - dan Agama (Yogyakarta: Kanisius, 1976), 67.
Maha Esa, gotong royong, tolong menolong antara satu dengan lainnya dan saling menghormati hubungan antara sesama manusia, alam sekitar dan Tuhan Yang Maha Esa. ${ }^{21}$

Pada era orde lama, pembahasan yang dilakukan oleh para founding father bangsa ini terkait frasa "Ketuhanan Yang Maha Esa" memunculkan perdebatan antara kelompok nasionalis dan Islamis. Menurut M. Yamin, frasa tersebut merupakan esensi yang mendasar dan penting terhadap kepercayaan yang telah ada di Indonesia, jauh sebelum datangnya agama Islam dan Kristen. M. Yamin berpendapat bahwa frasa "Ketuhanan Yang Maha Esa" berasal dari kepercayaan agama lokal, kemudian cakupannya diperkaya melalui datangnya misi-misi doktrinal. ${ }^{22}$

Adapun keberadaan agama-agama lokal di Nusantara telah ada sejak dahulu, jauh sebelum datangnya agama-agama yang diakui oleh pemerintah. Agama-agama lokal di Nusantara, diantanya ialah Towani Tolotang, Ammatoa, dan Aluk Todolo yang berada di Sulawesi Selatan, Kepercayaan Sakai di Riau, Bubun dan Sunda Wiwitan di Jawa Barat, Sedulur Sikep dan Sapta Darma di Jawa Timur, Islam Wetu Telu di Lombok, dan Marapu di Sumba, Nusa Tenggara Timur. Agama-agama tersebut telah menjadi identitas keagamaan masyarakat lokal setempat pada zaman dahulu yang dapat bertahan sampai dengan saat ini. Namun, penganut agama lokal kerap menjadi objek perlakuan diskriminatif baik oleh masyarakat penganut agama resmi maupun melalui kebijakan diskriminatif negara dalam mengintervensi hidup dan kehidupan para penganut agama lokal.

Dampaknya, para penganut agama lokal menjadi kehilangan hak-hak sipil dan pelayanan publiknya, serta memunculkan konflik di masyarakat karena penganut agama lokal akan dianggap orang yang sesat dan cenderung

${ }^{20}$ Moh. Soehada, Metode Penelitian Sosial Kualitatif Untuk Studi Agama (Yogyakarta: Suka Press, 2012), 17.

${ }^{21}$ Suhanah, ed. Dinamika Agama Lokal di Indonesia, (Jakarta: Puslitbang Kehidupan Keagamaan Badan Litbang dan Diklat Kementerian Agama, 2014), 5.

${ }^{22}$ Ismatu Ropi, "Religion and Regulation in Indonesia"..., 96. 
dipinggirkan dalam tatanan kehidupan sosial di masyarakat. Akhirnya mereka tidak dapat membentuk identitas mereka sendiri sebagai sebuah komunitas, namun sebagaimana yang diungkapkan oleh Yohannes Mauritz, mereka dibentuk oleh orang lain yakni negara, bukan mereka sendiri yang membentuk identitas dan jati dirinya. ${ }^{23}$

Selain itu mereka menjadi sasaran dakwah baik Islamisasi, Kristenisasi, Hinduisasi atau Budhanisasi. Mereka menjadi objek sasaran agama mayoritas atau agama tertentu yang telah diakui oleh negara untuk diajak masuk atau memeluk agama-agama resmi. ${ }^{24} \mathrm{Hal}$ ini terjadi karena definisi agama yanng diterapkan oleh negara sangat bias, baik bias politik atau bias kepentingan agama tertentu. Definisi tersebut juga akan menempatkan para penganut agama lokal sebagai komunitas atau golongan yang belum beragama sehingga tidak jarang, mereka dianggap orang yang sesat, pelaku bid'ah atau sebutan-sebutan lainnya yang sudah barang tentu menjadi sebuah perlakuan dan tindakan yang diskriminatif. Secara tidak sadar bahwa negara telah melakukan sebuah hegemoni yang membuat sistem yang sangat kaku dan terbatas melalui pengakuan agama. Sehingga tindakan dan perlakuan yang diskriminatif kerap dialami oleh para penganut agama lokal ketika mereka dihadapkan pada persoalan pengurusan dokumen kependudukan, melamar pekerjaan, mencatatkan pernikahan dan lain-lain.

Padahal, di dalam konstitusi melarang tindakan diskriminatif, hal ini tertuang dalam Pasal 28 UUD 1945 yang secara jelas menyatakan bahwa "Setiap orang berhak dan bebas dari perlakuan yang bersifat diskriminatif atas dasar apapun dan berbak

23Yohannest Mauritz, "Agama Kaharingan Bukan Budaya': Catatan Proses Inklusif Agama Lokal Melalui Revitalisasi Nilai (Studi Orang-Orang Kaharingan di Desa Rubung Buyung Sampit Kalimantan Tengah)," in Intoleransi, Revitalisasi Tradisi dan Tantangan Kebinekaan Indonesia, ed. Ahmad Suaedy (Jakarta: Abdurahman Wahid Center, 2017), 129.

${ }^{24}$ Abd. Aziz Faiz, "Kebijakan Negara Dalam Mengakomodir Agama Pribumi Perspektif SosialAntropologi," Jurnal Pemberdayaan Masyarakat: Media mendapatkan perlindungan terhadap perlakuan yang bersifat diskriminatif itu." Terkait dengan perlakuan atau tindakan diskriminatif, Koesparmono memberikan gagasannya terkait dengan anggapan diskriminasi. ${ }^{25}$ Pertama, diskriminasi itu muncul karena adanya perilaku yang membedakan baik secara positif atau negatif berdasarkan ras, agama, gender, umur, bahasa, mental, kondisi ekonomi, dan sebagainya. Kedua, terkait dengan agama.

Dalam hal ini negaralah yang menentukan apakah agama yang dianut oleh kelompok tertentu merupakan agama atau tidak. Dari kedua gagasan tersebut bahwa, gagasan diskriminasi dapat muncul dari adanya pembedaan ras, gender, bahasa dan agama serta pengakuan agama yang dilakuakan oleh negara. Penentuan agama yang dilakukan oleh negara melalui pengakuan agama resmi dan tidak resmi, memunculkan perlakuan diskriminasi terhadap penganut agama lokal, yang agamanya tidak diakui oleh pemerintah dan memandang mereka sebagai orang yang tidak beragama. Padahal tujuan negara adalah sebagai pencipta dan penjaga kesejahteraan sebagaimana yang dijelaskan oleh Plato dan Aristoteles yang menempatkan kesejahteraan masyarakat sebagai hukum yang posisinya sangat tinggi bagi negara dan penguasanya. ${ }^{26}$

Oleh karena itu, negara harus selalu berada pada posisinya yaitu berusaha untuk melindungi Hak-hak Asasi Manusia (HAM) warga negaranya. Ada tiga kewajiban negara yang harus dan mesti dipenuhi. ${ }^{27}$ Pertama, kewajiban dalam konteks menghormati (to respect) Hak-hak Asasi Manusia (HAM) yang melekat pada warga negaranya dan negara tidak boleh mengkooptasi atau membatasi hak-hak ini. Kedua, kewajiban untuk menjaga serta

Pemikiran Dan Dakwah Pembangunan, (2019): 233, https://doi.org/10.14421/jpm.2018.022-01.

${ }^{25} \mathrm{~A}$. Masyhur Efendi dan Taufani Sukmana Evandri, HAM Dalam Dimensi/Dinamika Yuridis, Sosial, Politik: Dan Proses Penyusunan/Aplikasi Ha-Kham (Hukum Hak Asasi Manusia) dalam Masyarakat (Bogor: Ghalia Indonesia, 2010), 77.

${ }^{26}$ Tedi Kholiludin, Kuasa Negara Atas Agama..., 81.

${ }^{27}$ Suryadi Radjab, Indonesia, Hilangnya Rasa Aman: Hak Asasi Manusia dan Transisi Politik Indonesia (Jakarta: PBHI dan The Asia Foundation, 2002), 12-13. 
melindungi (to protect) Hak-hak Asasi Manusia dengan menghapus aturan, regulasi atau kebijakan yang diskriminatif sebagai bentuk perlindungan negara terhadap Hak-hak Asasi Manusia. Ketiga, kewajiban untuk berusaha secara maksimal memenuhi (to fulfill) Hak-hak Asasi Manusia (HAM) dengan memberikan segala akses formal pelayanan-pelayanan publik.

\section{UU NOMOR 1/PNPS TAHUN 1965 DAN PLURALITAS TERBATAS}

Latar belakang lahirnya Undang-undang Nomor 1/PNPS Tahun 1965 Tentang Pencegahan Penyalahgunaan dan/atau Penodaan Agama adalah untuk mengatasi dan mengantisipasi aliran-aliran atau organisasi kepercayaan yang dianggap tidak sesuai dengan ajaran pokok Agama yang ada. Usaha yang dilakukan oleh negara dengan memformulasikan suatu kebijakan atau peraturan di bidang agama merupakan suatu cara dalam memberikan jaminan pelayanan dalam beribadah bagi pemeluk agama, sehingga mereka dapat menjalankannya dengan aman dan tenteram.

Pada dasarnya, urusan agama merupakan ranah privat dan sifatnya menyangkut pribadi. Namun, dalam relasinya pada tataran kerukunan umat beragama dan kebebasan beragama, negara harus memiliki inisiatif dalam memberikan perlindungan hukum. Oemar Seno Adji mengemukakan tiga pandangannya, terkait konsepsi perlindungan agama, yakni: ${ }^{28}$

1. Friedensschutr, theory, memandang "der religiosce interkon fessionelle Feriede" sebagai kepentingan hukum yang harus dilindungi;

2. Gefüblsschutz-theorie yang hendak melindungi rasa keamanan sebagai "das heiligste Innenleben der Gesammtheit",

3. Religionsshutz-theori, dikemukakan oleh Kohler dan Kahl, yang beranggapan bahwa agama

${ }^{28}$ Oemar Seno Adji, Perkembangan Hukum Pidana dan Hukum Acara Pidana Sekarang dan di Masa yang akan Datang (Jakarta: Pantjuran Tujuh, 1983), 50.

${ }^{29}$ Oemar Seno Adji, Herziening-Ganti Rugi, Suap, Perkembangan Delike (Jakarta: Erlangga, 1984), 297. sebagai kepentingan hukum yang harus diamankan oleh negara

Dalam menangani dan mengatasi kejahatan terhadap agama, negara cenderung menggunakan Religionsshutz-theori karena tujuan pengaturan dalam UU N.1/PNPS Tahun 1965 adalah untuk mengamankan kepentingan hukum atas agama yang dianut di Indonesia. Oemar Seno Adji juga mengemukakan konsep blasphemy atau penodaan agama. Tujuan dari konsepsi tersebut adalah sebagai causa prima dari sila pertama "Ketuhanan Yang Maha Esa", yang tidak mempunyai afweer atau pertahanan terhadap serangan dan ejekan terhadap Tuhan. ${ }^{29}$ Munculnya konsep blasphemy kala itu dikarenakan banyaknya kasus penodaan agama serta praktik keagamaan yang telah menyimpang jauh dari aturan agama. ${ }^{30}$ Sehingga dikeluarkannlah sebuah pengaturan sebagaimana yang tertuang dalam Undang-undang Nomor 1/PNPS Tahun 1965.

Adapun poin-poin pembahasan dan penjelasan yang terdapat pada UU No. 1 PNPS 1965, semakin menegaskan bagaimana bentuk relasi dan kuasa negara terhadap agama melalui sebuah politik pengakuan. Hal tersebut tergambar dalam penjelasan UU No. 1/PNPS/1965 pada bagian I (Umum) poin kedua yang menyebutkan "Telah ternyata, babwa pada akbir-akbir ini hampir di selurub Indonesia tidak sedikit timbul aliran-aliran atau munculnya organisasi-organisasi kebatinan/kepercayaan masyarakat yang bertentangan dengan ajaran-ajaran dan bukum agama. Diantara ajran-ajaran atau perbuatanperbuatan pada pemeluk aliran-aliran tersebut sudah banyak yang telah menimbulkan hal-hal yang melanggar bukum, memecab persatuan nasional dan menodai agama. Dari kenyataan teranglah, babwa aliran-aliran atau organisasi kebatinan/kepercayaan masyarakat yang menyalahgunakan dan/atau mempergunakan agama sebagai pokok, pada akbir-akhir ini bertambah banyak dan telah berkembang ke arah yang sangat membahayakan

\footnotetext{
30Soedarto, Hukum Pidana dan Perkembangan Masyarakat: Kajian terhadap Pembaharuan Hukum Pidana"(Bandung: Sinar Baru, 1983), 78.
} 
agama-agama yang ada". Kemudian pada poin ke lima dalam UU PNPS dijelaskan bahwa "..dengan penetapan Presiden ini tidaklah sekali-sekali dimaksudkan hendak mengganggu gugat hak bidup agama-agama yang sudah diakui oleh Pemerintah sebelum Penetapan Presiden ini diundangkan."

Dari penjelasan mengenai UU No. 1 PNPS tahun 1965 sebagaimana yang telah dipaparkan di atas, penulis menggaris bawahi beberapa kata-kata dalam kalimat tersebut, yakni agama-agama yang ada dan agama-agama yang sudah diakui. Kedua frasa tersebut merujuk pada agama-agama resmi yang diakui di Indonesia, yakni Islam, Kristen, Katholik, Hindu, Buddha, dan Konghucu yang mendapatkan pengakuan sebagai Agama pada Era Reformasi di bawah pemerintahan Presiden Abdurrahman Wahid (Gus Dur).

Berkaitan dengan adanya agama-agama tertentu yang secara resmi mendapatkan pengkuan atau recognize oleh pemerintah, Julia Howell memberikan pengertian yang lebih eksplisit menegenai agama-agama yang diakui tersebut dengan istiah limited pluralism atau pluralitas terbatas. ${ }^{31}$ Sehingga apabila seseorang tidak memeluk agama yang resmi diakui oleh pemerintah, maka dia akan dianggap sebagai ateis. Sedangkan ateisme itu tidak akan pernah menjadi pilihan bagi orang yang ingin dianggap sebagai warga negara yang baik, serta dapat terbebas dari tuduhan komunis. Dalam perspektif yang lain, Elizabeth S. Hurd mengkategorikan agama-agama yang diakui oleh negara sebagai Governed Religion atau agama yang diregulasi. Maksudnya adalah agama serta pendefinisian terhadap agama dikonstruksi oleh kelompok yang memiliki otoritas dan power, baik secara politik maupun agama. Sehingga mereka mempunyai wewenang dan kapasitas dalam menentukan mana yang disebut agama, dan mana yang bukan agama. ${ }^{32}$

${ }^{31}$ Julia D. Howell, "Muslims, the New Age and Marginal Religions in Indonesia: Changing Meanings of Religious Pluralism," Social Compass, (2005): 447, https://doi.org/10.1177/0037768605058151.

${ }^{32}$ Elizabeth Shakman Hurd, Beyond Religious Freedom: The New Global Politics of Religion, (Princeton NJ: Princeton
Dampak yang ditimbulkan dari adanya pluralisme terbatas tersebut mengakibatkan adanya celah yang berpotensi menjadi persoalan yang cukup krusial bagi negara khususnya dalam pola pengaturan negara terhadap agama-agama lokal. Adapun celah yang berpotensi menjadi persoalan tersebut yakni pada kebijakan-kebijakan yang dibuat oleh negara terhadap para penganut agama lokal dikhawatirkan cenderung diskriminatif dan bersifat memaksa.

Hubungan dan kuasa negara atas agama di Indonesia sangat beragam, hal ini dapat dilihat dari adanya pengakuan negara terhadap beberapa agama dan membatasi agama yang dianggap mengganggu, sebagaimana yang dijelaskan dalam UU No. 1/PNPS $/ 1965^{33}$ Hal inilah yang kemudian menjadi pegangan pemerintah untuk membuat sebuah dikotomi antara agama resmi dan tidak resmi. Dengan adanya dikotomi tersebut negara menunjukkan bahwa negara memiliki relasi dan kuasa atas agama dalam pengelolaan agama, sehingga agama-agama yang tidak resmi mendapatkan perlakuan yang diskriminatif dan diposisikan sebagai agama yang menjadi sasaran dakwah atau pencerahan bagi gerakan-gerakan penyadaran keagamaan.

Adapun dampak yang ditimbulkan dengan diberlakukannya UU Nomor/PNPS Tahun 1965 terhadap kehidupan beragama adalah sebagai berikut, yakni:

1. Pembatasan ajaran agama.

Relasi seseorang dengan sebuah agama di Indonesia dikaitkan pada UUD 1945 yang mengharuskan dan mewajibkan bagi setiap orang untuk beragama. Sehingga seseorang tidak diperbolehkan untuk tidak beragama. Sebagaimana yang tertuang dalam Pasal 29 dan Pasal 28E ayat(1) UUD 1945 bahwa setiap

University Press, 2015), 8, https://doi.org/10.1093/ia/iix014.

${ }^{33}$ Mark Woodward, "Hubungan Agama-Negara di Indonesia: Sebuah Perspektif Komparatif" dalam Bernard Adeney Risakotta, Mengelola Keragaman di Indonesia: Agama dan Isu-isu Globalisasi, Kekerasan, Gender, dan Bencana di Indonesia (Bandung: Mizan Pustaka, 2015), 65. 
orang diberi kebebasan untuk memilih agama, bukan tidak memilih untuk beragama.

2. Agama resmi menjadi indikator bagi aliranaliran kebatinan atau kepercayaan.

Dampak yang kedua dari diberlakukannya UU tersebut adalah agama-agama yang telah mendapatkan pengakuan oleh negara menjadi standar uji bagi aliran-aliran kepercayaan atau kebatinan. Sehingga apabila terdapat aliran yang memiliki tindakan tidak sesuai dengan ajaran agama yang telah diakui, maka hal demikian merupakan tindakan yang dilarang.

3. Ruang bagi aliran kepercayaan yang bersendikan Ketuhanan Yang Maha Esa.

Secara yuridis, lahirnya UU No.1/PNPS 1965 adalah untuk membendung pengaruh dari aliran-aliran kepercayaan dan kebatinan. Mengingat bahwa definisi agama yang diadopsi oleh agama atau kepercayaan lokal tidak merepresentasikan elemen esensial agama resmi, sehingga para penganut agama lokal hanya dibatasi pada tataran keyakinan kepada Tuhan Yang Maha Esa.

\section{POLA EKSISTENSI PENGANUT AGAMA LOKAL DI TENGAH PLURALITAS TERBATAS}

Pada tahun 1973, para penganut agama lokal telah mendapatkan pengakuan setara dengan agama dunia melalui Tap MPR No. IV/1973, bahwa agama (dunia) dan kepercayaan (agama lokal) diperlakukan setara dengan agama: yakni diakui, dilayani, dan bahkan dikembangkan. Namun, setelah munculnya Tap MPR No. IV/1978 memberikan sebuah stigmatisasi atau label baru bagi agama lokal bahwa "kepercayaan adalah budaya, bukan sebuah agama". Konsekuensi logisnya adalah pengikut agama lokal hanya dianggap berbudaya, namun belum dianggap beragama. ${ }^{34}$ Lahirnya UU Nomor 1/PNPS Tahun 1965 Tentang Pencegahan Penyalahgunaan dan/atau Penodaan Agama, kian mempersempit ruang gerak penganut agama lokal dalam mengekspresikan agama dan kepercayaannya di Indonesia.

Dalam konteks dikotomi agama resmi dan tidak resmi yang dialami oleh penganut agama lokal, mengakibatkan munculnya tindakan diskriminatif, kriminalisasi dan pembedaan akses pelayanan dan pemenuhan hak-hak konstitusionalnya, baik dari masyarakat ataupun kebijakan negara. Sehingga penganut agama lokal berusaha untuk tetap mempertahankan keberlangsungan atau eksistensinya dengan beberapa pola atau strategi.

Secara umum, ada tiga strategi atau pola yang dilakukan oleh penganut agama lokal, yakni:

1. Konversi Agama

Pilihan untuk pindah agama bagi para penganut agama lokal merupakan pilihan yang sulit. Perpindahan ini dilakukan atas dasar peraturan perundang-undangan yang tidak mengakomodasi mereka sebagai kelompok identitas yang diakui oleh negara. Sehingga, apabila mereka memilih untuk konversi atau pindah pada agama-agama resmi yang diakui negara, maka kebutuhan dan hak-hak mereka akan terakomodasi. Salah satu contoh agama lokal yang melakukan konversi agama, dari agama lokal ke agama resmi ialah Towani Tolotang. Agama Towani Tolotang terletak di Kabupaten Sidrap Provinsi Sulawesi Selatan. Towani Tolotang dikonversi menjadi Agama Hindu, sesuai dengan kepurtusan Direktorat Jenderal Bimbingan Masyarakat (BIMAS) Hindu Bali/Buddha No. 2 Tahun 1966 yang menyebutkan bahwa Towani Tolotang merupakan salah satu bagian dari sekte agama Hindu.

Dengan adanya surat keputusan tersebut maka secara otomatis segala hal yang berkaitan dengan keperluan administrasi baik kependudukan maupun pencatatan perkwainan berkiblat pada agama Hindu. Hal 
serupa juga terjadi pada penganut agama Kabaringan di Kota Palangkaraya Kalimantan Tengah. Majelis Besar Alim Ulama Kaharingan Indonesia (MB-AUKI) yang terbentuk setelah Serikat Kaharingan Dayak Indonesia (SKDI) mengajukan integrasi kepada Parisada Hindu Dharma Indonesia (PHDI) pusat. Surat pengajuan tersebut tertulis Nomor 5/KU/MB-AUKI/1980 tertanggal 1 Januari 1980 tentang penggabungan/integrasi Mejelis Besar Agama Hindu Kaharingan (MB-AHK) dengan PHDI. ${ }^{35}$ Kemudian ditindaklanjuti oleh Kepala Kantor Wilayah (Kakanwil) Departemen Agama Kalimantan Tengah dengan menerbitkan SK No. MA 203/1980 Tentang Pengintegrasian Agama Lokal Kaharingan Menjadi Agama Hindu. ${ }^{36}$ Hal ini dilakukan oleh para penganut agama Kaharingan untuk menghindari adanya stereotipe negatif dari masyarakat di sekitar mereka yang selalu memposisikan mereka sebagai orang yang tidak beragama dan untuk memudahkan berbagai macam urusan yang berkaitan dengan administrasi kependudukan.

2. Sinkretisme Agama

Selain melakukan konversi agama, adapula strategi-strategi lainnya yang dimainkan oleh para penganut agama lokal untuk mempertahankan keberlangsungan atau eksistensinya yakni dengan sinkretisme. Sinkretisme mengasumsikan bahwa suatu agama begitu murni (pure) sehingga dapat dibedakan dengan agama lainnya. ${ }^{37}$ Mereka memandang dan memahami agama itu inklusif, bukan eksklusif. Artinya di satu sisi mereka mengakui diri mereka beragama, misalkan beragama Islam, namun di sisi lain mereka juga menganut dan mengikuti agama

${ }^{35}$ Wakhid Sugiyarto, "Eksistensi Agama Hindu Kaharingan di Kota Palangkaraya Kalimantan Tengah", Jurnal Multikiltural dan Multireligius 15, no. 3 (Desember 2016): 108.

${ }^{36}$ Sukirno, "Diskriminasi Pemenuhan Hak Sipil Bagi Penganut Agama Lokal," Administrative Law and Governance Journal, (2018): 237, https://doi.org/10.14710/alj.v1i3.231-239. lokal sebagai identitas mereka. Contohnya adalah penganut agama Islam Ammatoa yang terletak di Desa Tanah Towa Kabupaten Bulukumba Provinsi Sulawesi Selatan. Sesuai dengan identitas agama yang tercantum di kolom agama KTP, mereka menganut agama Islam. Namun dalam pengimplementasiannya mereka tidak melaksanakan syari'at-syari'at Islam seperti sholat, zakat, puasa dan haji. Mereka hanya mengakui Islam sebagai agamanya namun tidak pada praktiknya. ${ }^{38}$ Artinya, agama Islam yang mereka yakini hanya sebagai lambang belaka atau yang biasa kita sebut sebagai Islam KTP. Tujuannya adalah hanya untuk memudahkan mereka dalam mengurus berbagai urusan yang berkaitan dengan dokumen administrasi kependudukan dan pencatatan sipil.

Demikian pula dengan pengikut Islam Wetu Telu di Kabupaten Lombok Utara. Dalam konteks identitas Keislaman, mereka menegaskan bahwa kelompoknya merupakan pengikut Islam. Namun, pada saat yang bersamaan, mereka menyatakan diri sebagai penganut Islam Wetu Telu. Hal ini menunjukkan bahwa terdapat sebuah dialektika antara Islam normatif dan Islam Kultural. Lahirnya Islam Wetu Telu di Lombok tidak lepas dari pengaruh akulturasi budaya dan kompromi kebudayaan. Dari paradigma inilah, lahir lah sebuah local indigenous. Pada sisi lain, local indigenous mampu bertahan terhadap pengaruh dan dominasi luar dengan tetap bertahan pada keyakinannya, atau

\footnotetext{
${ }^{37}$ Samsul Maarif, "Meninjau Ulang Definisi Agama, Agama Dunia, dan Agama Leluhur"..., 36.

${ }^{38}$ Abdul Hafid, "Sistem Kepercayaan Pada Komunitas Adat Kajang Desa Tanah Towa Kecamatan Kajang Kabupaten Bulukumba," Patanjala: Jurnal Penelitian Sejarah Dan Budaya, (2013): 8, https://doi.org/10.30959/patanjala.v5i1.150.
} 
mengakomodasi unsur-unsur dunia luar melalui sinkretisme. ${ }^{39}$

3. Resistensi

Resistensi merupakan upaya yang dilakukan oleh para penganut agama lokal dalam menolak tawaran konversi atau pindah agama yang ditawarkan oleh negara. Contohnya adalah masyarakat suku Sakai. Ketika Sultan Siak mengadakan proyek Melayunisasi yang bersamaan dengan proses Islamisasi terhadap Suku Sakai. Namun, Suku Sakai menolak untuk melakukan konversi agama. Begitupun pada era Orde Baru, pemerintah melakukan marginalisasi bagi masyarakat Sakai dengan mengeksploitasi lahan yang dihuni masyarakat Sakai untuk proyek pembangunan tanpa adanya pelibatan masyarakat Sakai. Cara-cara tersebut sengaja dilakukan agar dapat mempersempit ruang gerak dan penyebaran mereka. ${ }^{40}$ Bentuk lain dari resistensi agama dapat dilihat dari apa yang ditampilkan oleh Agama Marapu. Agama lokal ini diafiliasikan dengan agama Kristen. Namun, mereka kerap mempertentangkan ajaran agama nenek moyang mereka dengan agama Kristen dan merasa bahwa agama leluhurnya lebih baik daripada agama Kristen, meskipun mereka sudah dikonversi ke agama tersebut. selain masyarakat Sakai dan Marapu, masyarakat Samin termasuk dari kelompok agama lokal yang menggunakan resistensi frontal terhadap segala bentuk afiliasi ke agama dunia. Masyarakat Samin dikenal pula dengan sebutan Sedulur Sikep.

Adapun resistensi Sedulur Sikep dalam menyikapi intervensi pemerintah dan muslim dalam ranah keagamaan, lebih didominasi secara silent protest. Yakni, segala kebijakan dan tawaran yang diberikan oleh negara terhadap

${ }^{39}$ Muhammad Harfin Zuhdi, "Islam Wetu Telu (Dialektika Hukum Islam dengan Tradisi Lokal). Istinbath, Jurnal Hukum Islam 13, no. 2 (Desember 2014): 174.

${ }^{40}$ Parsudi Suparlan, Orang Sakai di Riau: Masyarakat Terasing dalam Masyarakat Indonesia (Jakarta: Yayasan Obor Indonesia, 1995), 73. penganut Sedulur Sikep, direspon secara patuh, namun mereka mendiaman instruksi dan perintah tersebut. Resistensi kepatuhan semu melalui silent protest telah dilakukan dalam beberapa kasus, misalnya larangan pencantuman agama atau kepercayaan Sedulur Sikep dalam administrasi kependudukan (KTP maupun Kartu Kelaurga), dan ditawarkan agar mengisi kolom identitas agama mereka, dengan Buddha atau Islam. Demikian pula saat melakukan perkawinan, mereka diinstruksikan untuk menikah secara Islam. Penganut Sedulur Sikep merespon tawaran dan instruksi tersebut secara patuh dan sukarela, tanpa melakukan perlawanan atau membantah tawaran tersebut.

Respon patuh tersebut, tidak serta merta menjadikan pengikut Sedulur Sikep menjalankan aturan dan ajaran agama duni yang dicantumkan dalam KTP maupun KK. Namun, tetap menjadikan mereka untuk konsisten menjalankan dan melaksanakan ajaran agamanya. Respon silent protest tersebut menjadi indikasi bahwa mereka menjadikan strategi resistensi sebagai senjata untuk melawan dominasi agama-agama dunia. ${ }^{41}$

Ketiga strategi di atas digunakan oleh para penganut agama lokal dalam merespon dikotomi dan pemaknaan agama yang dikonstruk oleh negara. Setiap komunitas, bisa saja memainkan satu, dua atau lebih strategi untuk dapat menavigasikan eksistensi mereka, meskipun mereka dianggap dan dikelompokkan sebagai warga negara kelas dua.

Seiring dengan berjalannya waktu, sebagian penganut kepercayaan mengajukan judicial review ke Mahkamah Konstitusi (MK) terkait dengan UU Administrasi Kependudukan. Mahkamah Konstitusi kemudian mengeluarkan putusan No.97/PUU-XIV/2016 tertanggal 18

${ }^{41}$ Nawari Ismail, "Strategi Bertahan Kelompok Agama Lokal”, Harmoni: Jurnal Multikultural dan Multireligius 14, no. 3 (September-Desember, 2015): 124. 
Oktober 2017 yang dalam amar putusannya MK menyatakan bahwa pasal 61 ayat (1) dan (2) serta pasal 64 ayat (1) dan (5) UU Adminduk bertentangan dengan Undang-undang Dasar Negara Republik Indonesia 1945 (UUD NRI 1945) dan tidak mempunyai kekuatan hukum yang mengikat secara bersyarat sepanjang tidak termasuk kepercayaan. ${ }^{42}$ Putusan MK tersebut kemudian ditindaklanjuti oleh Kementerian Dalam Negeri (Kemendagri) dengan menerbitkan Surat Edaran (SE) yang mengakomodir kepercayaan terhadap Tuhan Yang Maha Esa dalam kolom agama di Kartu Keluarga dan Kartu Tanda Penduduk. Keputusan ini merupakan sebuah jawaban bagi masyarakat penganut agama lokal yang selama ini hak-hak sipilnya tidak terlayani dengan maksimal, khususnya dalam pengurusan administrasi kependudukan. Karena, selama ini para penganut agama lokal dihadapkan pada dua pilihan saat mengisi kolom agama di KTP. Pertama, menulis kolom tersebut dengan agama yang diakui oleh pemerintah. Kedua, mengosongkan kolom agama tersebut.

\section{PENUTUP}

Pendefinisian agama yang dikonstruksi oleh negara sarat dengan kepentingan kekuasaan dan agama. Selain itu, definisi mengenai agama yang diformulasikan di Indonesia bersifat esensialis dan etnosentris, berdasarkan agama mayoritas, yakni agama Islam. Terminologis tersebut cenderung bersifat teologis dan bias politis karena hanya mengakomodasi agamaagama tertentu yang telah mendapatkan pengakuan negara. Implikasi dari pendefinisian agama, pada akhirnya menuai polemik, dikarenakan agama lokal sebagai suatu keyakinan dan kepercayaan yang telah termanifestasi dalam kultur masyarakat lokal sejak turun-temurun, tidak dianggap dan diakui oleh negara sebagai suatu agama. Lahirnya Undang-undang Nomor 1/PNPS Tahun 1965 Tentang Pencegahan Penyalahgunaan dan/atau Penodaan Agama, kian memperumit ruang gerak penganut agama lokal dalam mengekspresikan kebebasan mereka dalam beragama dan berkeyakinan. Undang-undang tersebut semakin mempertegas superioritas agama-agama dunia yang mendapatkan pengakuan negara. Sehingga agama-agama lokal dianggap menjadi ancaman bagi agama-agama dunia. Maka Undang-undang tersebut bertujuan untuk membendung agama resmi dari pengaruh agama lokal.

Padahal di dalam Undang-Undang Dasar Tahun 1945 Pasal 28E Ayat (1) dan Pasal 29 Ayat (2) secara jelas dan tegas bahwa negara menjamin kemerdekaan dan kebebasan beragama bagi tiaptiap penduduknya. Namun undang-undang tersebut tidak sejalan dengan pengimplementasiannya di lapangan.

Munculnya Undang-undang Nomor 1/PNPS Tahun 1965 merupakan sebuah antitesa tentang kemerdekaan dan kebebasan beragama. Faktanya, UU tersebut dijadikan oleh negara sebagai sebuah pedoman untuk membatasi dan mempersempit kebebasan beragama. Hal ini tergambar dari adanya pengakuan negara terhadap agama-agama resmi di Indonesia, yakni Islam, Kristen, Katholik, Hindu, Buddha, dan Konghucu. Pengakuan ini dikenl dengan istilah pluralitas terbatas. Pengakua negara terhadap agama terlihat sangat paradoks. Karena UUD 1945 menjamin kebebasan dalam beragama dan berkeyakinan. Namun, muncul UU No.1/PNPS/1965 yang membatasi dan mengekang kebebasan tersebut.

Pembatasan ini, merupakan implikasi dari pendefinisian agama yang belum memiliki kemapanan. Sehingga, pendefinisian agama lebih didasarkan pada kelompok agama tertentu yang menjadi pionir serta prototipe bagi agama lainnya. Dengan demikian maka, penganut agama lokal akan terus berada di bawah bayang-bayang penodaan terhadap agama yang dapat mengancam eksistensi atau keberlangsungannya.
42 Rachmanto, "Era Baru Agama Lokal," dalam https://m.detik.com/news/kolom/d-3726048/era-baruagama-lokal, diakses tanggal 19 Desember 2020. 
Adapun pola dan strategi yang digunakan oleh penganut agama lokal dalam mempertahankan eksistensinya adalah dengan melakukan konversi atau pindah agama, sinkretisme agama, dan resistensi, yakni menolak untuk diafiliasikan dengan agama dunia. Pilihanpilihan ini tentunya sangat sulit. Karena, di satu sisi para penganut agama-agama leluhur atau lokal ingin tetap mempertahankan serta meneruskan eksistensi ajaran agama dan kebudayaan mereka yang secara turun temurun telah dipraktikkan. Namun, di sisi lain para penganut agama lokal dihadapkan pada berbagai kebijakan negara yang mengkooptasi hak-hak mereka, terutama hak-hak sipil dalam pelayanan dan pemenuhan kebutuhannya, baik pencatatan sipil, akses pendidikan, sarana dan fasilitas kesehatan, hingga pencatatan perkawinan.

\section{DAFTAR KEPUSTAKAAN}

Aziz Faiz, Abd. "Kebijakan Negara Dalam Mengakomodir Agama Pribumi Perspektif Sosial-Antropologi." Jurnal Pemberdayaan Masyarakat: Media Pemikiran Dan Dakwah Pembangunan,(2019), https://doi.org/10.14421/jpm.2018.022-01.

Abidin Bagir, Zainal. "Mengkaji Agama di Indonesia", dalam Samsul Ma'arif, Studi Agama di Indonesia: Refleksi Pengalaman. Yogyakarta: CRCS-UGM, 2016.

Abidin Bagir, Zainal, Moh. Iqbal Ahnaf, Marten

Tahun, Budi Asyhari. Laporan Tahunan Kebidupan Beragama di Indonesia 2012. Yogyakarta: Program Studi Agama dan Lintas Budaya Universitas Gadjah Mada, 2012.

Arafat, Yasser. "Analisis Undang-Undang Nomor 1/PNPS/ Tahun 1965 Tentang Pencegahan Penyalahgunaan dan/atau Penodaan Agama." Skripsi., Universitas Sebelas Maret, 2010.

Boon, James A. "Mysticism and Everyday Life in Contemporary Java: Cultural Persistence and Change. By Niels Mulder. Singapore:
Singapore University Press, 1978, Xix, 150 Pp. Appendix, Glossary, Bibliography, Index. N.p.L." The Journal of Asian Studies (1979), https://doi.org/10.2307/2053491.

Christianto, Hwian. "Arti Penting Pemberlakuan UU No. 1/PNPS/1965." Jurnal Hukum \& Pembangunan 41, no. 3 (2011), https://doi.org/10.21143/jhp.vol41.no3.2.1. Efendi, A. Masyhur dan Taufani Sukmana Evandri. HAM Dalam Dimensi/Dinamika Yuridis, Sosial, Politik: Dan Proses Penyusunan Aplikasi Ha-Kham (Hukum Hak Asasi Manusia) dalam Masyarakat. Bogor: Ghalia Indonesia, 2010.

Hafid, Abdul. "Sistem Kepercayaan Pada Komunitas Adat Kajang Desa Tanah Towa Kecamatan Kajang Kabupaten Bulukumba." Patanjala: Jurnal Penelitian Sejarah Dan Budaya, (2013),https://doi.org/10.30959/patanjala.v $5 i 1.150$

Howell, Julia D. "Muslims, the New Age and Marginal Religions in Indonesia: Changing Meanings of Religious Pluralism." Social Compass, (2005) https://doi.org/10.1177/003776860505815 1.

Hurd, Elizabeth Shakman. Beyond Religious Freedom:

The New Global Politics of Religion. Princeton NJ: Princeton University Press, 2015, https://doi.org/10.1093/ia/iix014.

Hanan, Abdul. "Fanatisme dan Stigma Sosial Pesantren Miftahul Ulum Terhadap Kelompok Ahmadiyah di Pamekasan." Tesis., Universitas Airlangga, 2006.

Ismail, Nawari. "Strategi Bertahan Kelompok Agama Lokal", Harmoni: Jurnlal Multikultural dan Multireligius 14, no. 3 (SeptemberDesember, 2015): 124.

J, Hasse. "Dinamika Hubungan Islam Dan Agama Lokal di Indonesia: Pengalaman Towani Tolotang Di Sulawesi Selatan." Wawasan: Jurnal Ilmiah Agama Dan Sosial Budaya, (2016), https://doi.org/10.15575/jw.v1i2.744. . "Kebijakan Negara Terhadap Agama Lokal 'Towani Tolotang' Di Kabupaten 
Sidrap, Sulawesi Selatan.” Journal of Government and Politics, (2010), https://doi.org/10.18196/jgp.2010.0009.

Krispendoff, Klaus. Analisis Isi Pengantar Teori Dan Metodologi. Yogyakarta Penerbit Kanisius, 1993.

Kholiludin, Tedi. Kuasa Negara atas Agama: Politik Pengakuan, Diskursus Agama Resmi dan Diskriminasi Hak Sipil. Semarang: RaSAIL, 2009.

Maarif, Samsul. "Meninjau Ulang Definisi Agama, Agama Dunia, dan Agama Leluhur" dalam Ihsan Ali Fauzi et.al., Kebebasan, Toleransi, dan Terorisme: Riset dan Kebijakan Agama di Indonesia. Jakarta: PUSAD Paramadina, 2017.

Mawaza, Jayyidan Falakhi and Rohit Mahatir Manese. "Pengikut Sapta Darma Di Tengah Pluralitas Terbatas," Palita: Journal of Social Religion Research, (2020), https://doi.org/10.24256/pal.v5i1.1273.

Mauritz, Yohannest. "Agama Kaharingan Bukan Budaya': Catatan Proses Inklusif Agama Lokal Melalui Revitalisasi Nilai (Studi Orang-Orang Kaharingan di Desa Rubung Buyung Sampit Kalimantan Tengah)," dalam Intoleransi, Revitalisasi Tradisi dan Tantangan Kebinekaan Indonesia, ed. Ahmad Suaedy. Jakarta: Abdurahman Wahid Center, 2017.

Ropi, Ismatu. Religion and Regulation in Indonesia. Singapore: Palgrave Macmillan, 2017, https://doi.org/10.1007/978-981-10-28274.

Radjab, Suryadi. Indonesia, Hilangnya Rasa Aman: Hak Asasi Manusia dan Transisi Politik Indonesia). Jakarta: PBHI dan The Asia Foundation, 2002.

Rachmanto, "Era Baru Agama Lokal," dalam https://m.detik.com/news/kolom/d-

3726048/era-baru-agama-lokal, diakses tanggal 19 Desember 2020.

Sukirno. "Diskriminasi Pemenuhan Hak Sipil Bagi Penganut Agama Lokal." Administrative Law and Governance Journal, (2018), https://doi.org/10.14710/alj.v1i3.231-239.

Subagya, Rahmat. Kepercayaan dan Agama. Yogyakarta: Kanisius, 1995.

Kerobanian - Kejiwaan - dan Agama.

Yogyakarta: Kanisius, 1976.

Soehadha, Moh. "Pengertian Antropologis Tentang Agama Dan Pengertian Oleh Negara Tentang Agama Di Indonesia."Esensia 6, no. 2 (Juli 2005): 189.

Metode Penelitian Sosial

Kualitatif Untuk Studi Agama. Yogyakarta: Suka Press, 2012.

Suhanah, ed. Dinamika Agama Lokal di Indonesia. Jakarta: Puslitbang Kehidupan Keagamaan Badan Litbang dan Diklat Kementerian Agama, 2014.

Seno Adji, Oemar. Perkembangan Hukum Pidana dan Hukum Acara Pidana Sekarang dan di Masa yang akan Datang. Jakarta: Pantjuran Tujuh, 1983.

Herziening-Ganti Rugi, Suap,

Perkembangan Delik. Cetakan Kedua. Jakarta: Erlangga, 1984.

Soedarto. Hukum Pidana dan Perkembangan Masyarakat: Kajian terbadap Pembaharuan Hukum Pidana. Bandung: Sinar Baru, 1983.

Sugiyarto, Wakhid. "Eksistensi Agama Hindu Kaharingan di Kota Palangkaraya Kalimantan Tengah", Jurnal Multikiltural dan Multireligius 15, no. 3 (Desember 2016): 10. Sudarto. "Rekognisi Agama Lokal Prasyarat Menuju Demokrasi Majemuk", Jurnal Fuaduna: Jurnal Kajian Keagamaan dan Kemasyarakatan 3, no. 2 (2019): 92-105, https://10.30983/fuaduna.v3i2.2547.

Suparlan, Parsudi. Orang Sakai di Riau: Masyarakat Terasing dalam Masyarakat Indonesia. Jakarta: Yayasan Obor Indonesia, 1995.

Wedasantara, Ida Bagus Oka and I Nyoman Suarsana. "Formalisasi Beragama Penganut Marapu Melalui Pendidikan Formal Pada Masyarakat Kampung Tarung Di Sumba Barat, NTT," Humanis, (2019), 
https://doi.org/10.24843/jh.2019.v23.i02.

p12.

Woodward, Mark. "Hubungan Agama-Negara di Indonesia: Sebuah Perspektif Komparatif' dalam Bernard Adeney Risakotta, Mengelola Keragaman di Indonesia: Agama dan Isu-isu Globalisasi, Kekerasan, Gender, dan Bencana di Indonesia. Bandung: Mizan Pustaka, 2015.

Zuhdi, Muhammad Harfin. "Islam Wetu Telu (Dialektika Hukum Islam dengan Tradisi Lokal)." Istinbath: Jurnal Hukum Islam 13, no. 2 (Desember 2014): 174. 